\title{
Kinerja Dinas Kependudukan dan Pencatatan Sipil Kabupaten Klungkung berdasarkan Metode Balance Scorecard
}

\author{
Komang Ayu Triska Prabandari ${ }^{1}$ \\ Fakultas Ekonomi dan Bisnis \\ Universitas Udayana, Indonesia. \\ Email: triskaprabandari24@gmail.com
}

\author{
I Gusti Ayu Made Asri Dwija Putri² \\ Fakultas Ekonomi dan Bisnis \\ Universitas Udayana, Indonesia.
}

\begin{abstract}
ABSTRAK
Penelitian bertujuan untuk menilai kinerja sesuai dengan misi dan tujuan Disdukcapil Kabupaten Klungkung menggunakan empat prespektif balance scorecard. Penelitian ini menggunakan data dari Laporan Kinerja Instansi Pemerintah (LKjIP) dan penyebaran kuesioner. Teknik analisis data pada penelitian ini mengunakan analisis deskriptif dengan menganalisis data dari keempat prespektif balance scorecard. Hasil dari penelitian ini adalah kinerja keuangan berdasarkan value for money dikategorikan cukup baik. Kinerja prespektif pelanggan dinilai dengan customers satisfaction index dikategorikan baik karena masyarakat merasa puas dengan pelayanan yang diperoleh. Kinerja prespektif proses internal dinilai dengan Service Cycle Efficiency (SCE) dan prespektif pertumbuhan dan pembelajaran dinilai menggunakan rasio produktivitas pegawai adalah baik.
\end{abstract}

Kata Kunci: Kinerja; Balance Scorecard; Perspektif; Value For Money

Performance of Population and Civil Registry Office of Klungkung Regency Based on Method of Balance Scorecard

\section{ABSTRACT}

The purpose of this research to assess the performance of the Disdukcapil Klungkung using four prescriptive balance scorecard. This research used data from the government agency performance report (LKjIP) and the dissemination of questionnaires. The data analysis techniques in research in using descriptive analysis by analyzing the data of the four-perspective balance scorecard. The results of this study show results of financial performance based on value for money categorized reasonably well. The performance of the customer is assessed by the customers satisfaction index categorized as well because the community is satisfied with the service provided. The performance of the internal process is assessed by Service Cycle Efficiency (SCE) and the perspective of growth and learning assessed by the employee's productivity ratio is good.

Keywords : $\quad$ Performance; Balance Scorecard; Prespective; Value For Money

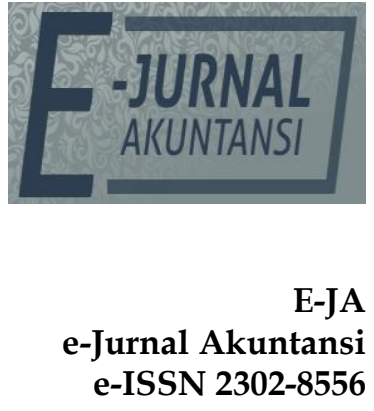

Vol. 29 No. 3

Denpasar, Desember

2019

Hal. 997-1011

Artikel masuk: 9 September 2019

Tanggal diterima: 6 November 2019 


\section{PENDAHULUAN}

Dinas Kependudukan dan Pencatatan Sipil (Disdukcapil) adalahu organisasi perangkat daerah Kabupaten Klungkung yang memberikan suatu pelayanan publik dalam bidang administrasi kependudukan. Disdukcapil Klungkung memiliki misi yaitu meningkatkan kualitas pelayanan pendaftaran penduduk dan pencatatan sipil dengan memberikan pelaynana yang cepat, tepat dan professional, terbentuk melalui Peraturan Daerah atau Perda No.9 tahun 2016 tentang Pembentukan dan Susunan Perangkat daerah Kabupaten Klungkung.

Disdukcapil Klungkung sejak tahun 2015 membuat inovasi secara bertahap untuk program baru dalam memberikan pelayanan kepada masyarakat. Program unggulan Pemkab Klungkung yang di laksanakan dengan sistem jemput bola ke lapangan memberikan keuntungan tersendiri kepada masyarakat karena didatangi secara langsung untuk mengurus administrasi kependudukan. Sistem jemput bola tersebut ternyata tidak begitu menguntungkan bagi masyarakat yang datang langsung ke kantor Disdukcapil Klungkung dikarenakan tidak mendapat pelayanan yang maksimal karena sebagian besar pegawai turun ke lapangan. Dikutip dari Balipuspanews tanggal 14/9/2018 hanya terdapat beberapa pegawai yang melayani warga yang mencari KTP-el di Kantor Disdukcapil. Dibagian pelayanan hanya ada 3 orang petugas yang melayani warga masyarakat Klungkung yang mau berurusan dengan KTP, Akte maupun Kartu Keluarga.

Program yang dilaksanakan dengan sistem jemput bola tersebut juga berdampak pada pegawai Disdukcapil Klungkung, dikarenakan keterbatasan anggaran petugas yang turun kelapangan tidak mendapat uang operasional atau intensif tambahan dari kantor. Sebagai lembaga sektor publik, instansi pemerintahan memiliki orientasi untuk lebih mengendepankan kepentingan publik dan tidak berorientasi pada laba sebagai tujuan akhirnya (Wood, 2010).

Disdukcapil Klungkung melaporkan pengukuran hasil kinerja tahunan serta evaluasi dan analisis akuntabilitas kinerja melalui Laporan Kinerja Instansi Pemerintah (LKjIP). Keberhasilan pencapaian visi dan misi instansi diukur dengan satu indikator kinerja utama yaitu Indeks Kepuasan Masyarakat. Pengukuran kinerja dengan satu indikator dirasa kurang memadai. LKjIP Disdukcapil Klungkung perlu memperhatikan aspek lainnya seperti tingkat ekonomis, efektifitas dan efisiensi penggunaan dana untuk program, belum ada penilaian mengenai proses yang penting bagi instansi untuk memberikan pelayanan seperti waktu pelayanan, dan penilaian produktivitas pegawai selaku pelaksana dari program yang telah ditetapkan. Penilaian dari berbagai aspek mampu digunakan untuk meningkatkan akuntabilitas dan kualitas pengambilan keputusan dan dalam instansi untuk menentukan strategi jangka pendek maupun jangka panjang sehingga mampu meningkatkan kinerja.

Penilaian kinerja diperlukan sebagai indikator penilai akuntanbilitas organisasi sektor public dalam tujuannya untuk menghasilkan pelayanan public yang tepat sasaran (Koufteros et al., 2014). Instansi pemerintahan Indonesia pertama yang pertama kali menerapkan konsep pengukuran aspek non keuangan adalah Kementrian Keuangan. Kementrian keuangan pada tahun 2008 menerapkan konsep balance scorecard sebagai alat pengukuran dimulai dari level atas, hal tersebut dilator belakangi oleh revormasi birokrasi bersekala nasional 
sebagaimana diatur di dalam Instruksi Presiden (Inpres) No. 5 Tahun 2004 tentang Percepatan Pemberantasan Korupsi. Balance scorecard adalah alat konseptual dari empat prespektif yang dapat dimodifikasi (Behrouzi et al., 2014).

Konsep balance scorecard berevolusi dari model perencanaan tahun 1990 menjadi sistem manajemen strategis terpadu yang menghubungkan strategi jangka panjang dan startegi jangka pendek (Ronchetti, 2006). Penelitian mengenai penilaian kinerja berdasarkan balance scorecard sebelumnya dilakukan oleh Nugrahini et al., tahun 2016 yang menilai kinerja pada Badan Penanaman Modal dan Perijinan Daerah Kabupaten Tabanan. Penelitian mengenai kinerja organisasi sektor publik/instansi pemerintah berdasarkan balance scorecard juga dilakukan oleh Limbu dan Sisdyani (2016), Ridwan et al., (2013), Wiguna dan Wirawati (2017), Pebrianata dan Putri (2014) serta A dan A (2013). Bolivar (2010) pada Aytül, (2014) mengindikasikan bahwa penerapan balance scorecard bisa menjadi alat ukur yang tak ternilai pada instansi pemerintahan. Teknik analisis data yang digunakan dalam penelitian berbeda-beda, tergantung pada masingmasing prespektif balance scorecard.

Konsep balance scorecard dikembangkan dengan tujuan melengkapi pengukuran kinerja tradisional (finansial) dan sebagai alat bagi organisasi untuk merefleksikan pemikiran baru dalam era kompetisi dan efektivitas organisasi. Konsep balance scorecard memperkenalkan system pengukuran kinerja dengan menggunakan kriteria-kriteria tertentu (Ciptani, 2013). Balance scorecard muncul dari kebutuhan untuk meningkatkan perencanaan, pengendalian, dan fungsi pengukuran kinerja Akuntansi Manajemen (Davis dan Albright, 2004).

Konsep Balanced Scorecard dapat digunakan sebagai basis dalam penyusunan rencana strategis untuk organisasi sektor privat maupun sektor publik (Dewi et al, 2017). Balanced scorecard memperhatikan semua ukuran baik keuangan dan nonkeuangan dalam tujuannya menjadikan visi dan strategi menjadi bagian yang penting pada setiap tingkat organisasi (Fitriyani, 2014). Balanced scorecard berkembang menjadi system manajemen strategi yang digunakan untuk menterjemahkan misi, tujuan dan strategi kedalam inisiatif strategi yang koheren dan terukur (Haryono, 2013).

Misi dari Disdukcapil Klungkung adalah Melaksanakan Pelayanan Administrasi Kependudukan yang Cepat, Tepat dan Profesional. Berdasarkan misi tersebut penelitin ingin menilai kinerja Disdukcapil Klungkung menggunakan prespektif balance scorecard karena keempat prespektik balance scorecard dapat memberikan penilaian dari misi dan tujuan yang ingin dicapai.

Tabel 1. Indikator Penilaian Kinerja pada LKjIP Disdukcapil Klungkung dan Indikator Penilaian Kinerja Balance Scorecard

\begin{tabular}{ll}
\hline \multicolumn{1}{c}{ LKJiP } & \multicolumn{1}{c}{ Balance scorecard } \\
\hline Efisiensi Penggunaan Dana & Value For Money \\
Indeks Kepuasan Masyarakat & Indeks Kepuasan Masyarakat \\
& Service Cycle Efficiency (SCE) \\
& Rasio Produktivitas Pegawai \\
\hline
\end{tabular}

Sumber : Data Penelitian, 2019

Indikator penilaian kinerja berdasarkan metode balance scorecard dapat membantu Disdukcapil Klungkung dalam menilai kinerja yang cepat, tepat dan professional sesuai dengan misi dan tujuan Disdukcapil Klungkung. Penilaian 
kinerja keuangan menggunakan value for money, mengukur tingkat ekonomis, efisiensi dan efektifitas dari alokasi dan anggaran penggunaan dana, dengan penilaian kinerja keuangan Disdukcapil Klungkung akan mampu menilai apakah penggunaan dana setiap tahunnya telah digunakan dengan baik tanpa ada kelebihan pengeluaran dari anggaran yang telah ditetapkan. Penilaian kinerja menggunakan indeks kepuasan masyarakat, Service Cycle Efficiency (SCE) dan Rasio Produktivitas Pegawai membantu Disdukcapil Klungkung untuk menilai bagaimana proses dari pelayanan yang diberikan oleh pegawai.

Penilaian kinerja dengan Indeks kepuasan masyarakat adalah hasil penilaian yang diberikan oleh masyarakat selaku pengguna pelayanan dari Disdukcapil Klungkung. Indeks kepuasan masyarakat dihitung berdasarkan kuesioner yang merujuk pada Keputusan MENPAN Nomor KEP/25/M.PAN/2/2004, memberikan kesempatan kepada masyarakat untuk memberikan penilaian tentang kinerja dan pelayanan yang diberikan oleh pegawai Disdukcapil Klungkung. Penilaian dengan Service Cycle Efficiency (SCE) menilai rasio waktu pelayanan yang diberikan dengan waktu pelayanan yang ditetapkan. Service Cycle Efficiency (SCE) memberikan penilaian tentang ketepatan waktu pelayanan yang diberikan oleh pegawai Disdukcapil Klungkung. Indikator penilaian rasio produktivitas pegawai menilai secara keseluruhan kinerja pegawai dalam menerbitkan dokumen kependudukan.

Penilaian kinerja berkembang dari pemikiran mengenai organisasi akan dapat beroprasi dengan stabil apabila terdapat indikator ukuran kinerja (Francosantos et al., 2012). Tujuan dari balance scorecard adalah untuk mengarahkan, membantu mengelola dan membantu mengubah strategi jangka panjang untuk mengelola kinerja organisasi (Sharma, 2009). Pelaksanaan balance scorecard di sektor publik jelas memiliki tantangan yang unik yang berasal dari sifat pertanggungjawabannya, dimana sektor publik memiliki tanggungjawab kepada masyarakat bukan kepada pemegang saham (Sharma dan Gadenne, 2011). Seyogyanya balanced scorecard mampu dikembangkan dan diaplikasikan oleh setiap instansi pemerintah untuk meningkatkan perannya dalam menjalankan fungsi-fungsi pemerintahan.

Rumusan masalah dari penelitian ini berdasarkan latar belakang di atas, adalah : Bagaimana kinerja Disdukcapil Klungkung berdasarkan empat Prespektif pada Balance scorecard. Tujuan dalam penelitian ini adalah : Untuk mengetahui kinerja Disdukcapil Klungkung berdasarkan empat Prespektif pada Balance scorecard.

Manfaat Teoritis dari penelitian adalah diharapkan penelitian ini memberikan referensi tambahan untuk pengembangan ilmu pengetahuan yang lebih luas dan lebih dalam mengenai metode balance scorecard. Manfaat praktis dari penelitian ini adalah sebagai bahan pertimbangan bagi Disdukcapil Klungkung untuk mengembangkan balance scorecard sebagai indikator penilaian agar bias mempertahankan dan meningkatkan kinerja pelaynaan untuk masyarakat dalam urusan administrasi kependudukan.

\section{METODE PENELITIAN}

Konsep penelitian ini adalah mengkaji kinerja Disdukcapil Klungkung menggunakan empat perspektif dari Balanced scorecard yaitu prespektif 
keuangan, prespektif pelanggan, prespektif proses internal, serta prespektif pertumbuhan dan pembelajaran. Keempat prespektif pada Balance scorecard dinilai menggunakan tolok ukur yang berbeda sesuai dengan hasil yang ingin dicapai dari kinerja keempat prespektif tersebut.

Objek penelitian ini adalah kinerja Dinas Kependudukan dan Pencatatn Sipil Kabupaten Klungkung yang diukur menggunakan empat prespektif Balance scorecard. Metode penentuan sampel yang digunakan menggunakan metode purposive sampling yaitu pemilihan sample secara tidak acak dan memiliki target atau tujuan tertentu sehingga populasi yang dipilih untuk dijadikan sample dapat dipilih menurut kriteria-kriteria yang ditentukan sehingga akan relevan dengan rancangan penelitian (Etikan et al., 2016). Sampel dalam penelitian ini adalah realisasi masyarakat yang melakukan perekaman KTP-el sebanyak 150.899 orang. Sesuai dengan rumus slovin jumlah sample masyarakat yang melakukan perekaman KTP-el adalah 100 orang.

Penelitian ini dilakukan dengan pengujian prespektif balance scorecard. Penilaian kinerja pada prespektif keuangan yaitu diukur menggunakan aspek pada value for money. Value for money menjadi pertimbangan yang lebih mendesak, terutama untuk organisasi sektor publik dan organisasi lainnya yang memegang aset infrastruktur fisik (Mcdonald et al., 2013) .

Konsep yang dapat digunakan untuk mengukur kinerja perspektif keuangan pada Disdukcapil Klungkung adalah value for money. Value for money adalah pengukuran anggaran belanja pada suatu organisasi, baik organiasi yang berorientasi pada laba atau sektor publik (Barnett et al., 2010). Elemen pada value for money yaitu Rasio ekonomi adalah melakukan pengukuran pada tingkat kehematan dari pengeluaran yang dilakukan oleh organisasi, pengukuran tersebut memerlukan data pengeluaran dan realisasi anggaran. Menurut Mahmudi (2010 : 84) pengukuran ekonomis dinyatakan dalam rumus berikut :

Ekonomis $=\frac{\text { Input }}{\text { Input Value }} \times 100 \%$.

Keterangan :

Input : Realisasi anggran

Input Value : Anggaran

Kriteria ekonomi menurut Mahsun (2006 : 186) adalah:

Kurang dari $100 \%=$ ekonomis.

Sama dengan $100 \%=$ ekonomi berimbang.

Lebih dari $100 \%$ = tidak ekonomis.

Rasio efisiensi diukur menggunakan rasio antara output dengan input. Output yang digunakan dalam penelitian ini adalah realiasi fisik atau hasil capaian dari kegiatan yang sudah dijalankan selama tahun 2018.

Efisiensi $=\frac{\text { Output }}{\text { Input }} \times 100 \%$

Keterangan :

Output : keluaran yang dicapai

Input : Realisasi anggaran

Kriteria Efisiensi menurut Prasetyo (2010 : 10) adalah :

$90 \%$ sampai $100 \%$ = Sangat Efisien

$80 \%$ sampai $89,99 \%=$ Efisien

$70 \%$ sampai 79,99\% = Cukup Efisien 
$60 \%$ sampai $69,99 \%$ = Kurang Efisien

Kurang dari $59,99 \%$ = Tidak Efisien

Menurut Maridasmo (2002: 134) Efektifitas merupakan hubungan antara keluaran dengan tujuan dan sasaran yang ingin dicapai. Efektifitas pada dasarnya berkaitan dengan pencapaian target atau tujuan kebijakan (Liando et al., 2014). Rumus efektifits menurut Arfan (2014) pada (YS dan Ulupui, 2016) adalah :

Efektifitas $=\frac{\text { CapaianKinerja }}{\text { TargetYang Ditetapkan }} \times 100 \%$

Kriteria Efektifitas menurut Sudiarsa (2016) dalam YS dan Ulupui (2018) adalah :

Diatas $100 \%$ = Sangat Efektif

$90 \%$ sampai $100 \%=$ Efektif

$80 \%$ sampai $90 \%$ = Sukup Efektif

$60 \%$ sampai $80 \%=$ Kurang Efektif

Kurang dari $60 \%=$ Tidak Efektif

Prespektif pelanggan dinilai menggunakan kuesioner tertutup untuk mengetahui tingkat kepuasan masyarakat selaku pengguna layanan terhadap kinerja Disdukcapil Klungkung. Penilaian prespektif pelanggan diukur dengan kuesioner dan dinilai tingkat kepuasannya menggunakan Customer Satisfaction Index. Setiap jawaban dari kuesioner diberi skor sesuai dengan ukuran ordinal, jawaban Sangat Setuju diberi skor 4, Setuju diberi skor 3, Tidak Setuju diberi skor 2, dan Sangat Tidak Setuju diberi skor 1. Dalam penilaiannya dilakukan tabulasi atas jawaban responden kemudian dihitung presentase tingkat persetujuan responden. Seperti yang dirumuskan oleh Sugiyono (2002: 79) dalam Limbu dan Sisdyani (2016) sebagai berikut:

$\mathrm{IKM}=$ Perceived Performance

Keterangan:

IKM = Indeks Kepuasan Masyarakat

$\mathrm{PP} \quad=$ Perceived Performance

Indeks kepuasan minimun, indeks kepuasan maksimal dan interval ditentukan terlebih dahulu sebelum menentukan skala indeks kepuasan masyarakatni. Rumus interval oleh Sugiyono (2002: 80) sebagai berikut:

IK maksimal $=\mathrm{R} \times \mathrm{PP} \times$ EXmaks

$\mathrm{IK}$ minimal $\quad=\mathrm{R} \times \mathrm{PP} \times \mathrm{EXmin}$.

Interval $\quad=($ IK maks - IK $\min )$

Keterangan:

$\mathrm{R} \quad=$ Jumlah responden keseluruhan

PP $=$ total pertanyaan

EX $\min =$ Skor minimal

EX maks $=$ Skor maksimal

Prespektif proses internal berhubungan dengan prespektif pelanggan, karena untuk memberikan kepuasan pelayanan bagi pelanggan perlu focus memperhatikan komponen yang diperlukan (Farooq dan Hussain, 2011). Pada penelitian ini prespektif proses internal diukur melalui efektifitas waktu proses dalam pelayanan yang diberikan pada waktu proses perekaman E-KTP, diukur menggunakan Service Cycle Efficiency (SCE). SCE menghitung rasio perbandingan antara waktu proses pelayanan perekaman KTP-el dengan standar waktu yang 
ditetapkan. Dalam perhitungan waktu pemerosesan, apabila rasio mendekati $100 \%$ akan menunjukkan tingkat koefisien dalam melakukan proses pelayanan (Meillinda dan Suartana, 2018).

Service Cycle Efficiency (SCE) $=\frac{\text { Processing Time }}{\text { Troughput Time }} \times 100 \%$

Sasaran dari prespektif Pertumbuhan dan pembelajaran adalah pencapaian produktivitas pegawai (Taufik et al., 2018). Pengukuran produktivitas pegawai bertujuan untuk membandingkan jumlah pegawai yang dikerahkan untuk menghasilkan keluaran dibandingkan dengan keluaran yang dihasilkan pegawai (Nugrahini et al., 2016). Pengukuran produktivitas pegawai diukur melalui jumlah data administrasi kependudukan yang dikeluarkan setiap tahunnya.

\section{HASIL DAN PEMBAHASAN}

Penilaian dengan balance scorecard pada kinerja instansi pemerintah memiliki keunggulan untuk menilai kinerja dari berbagai aspek. Balance scorecard menerjemahkan misi dan strategi kedalam berbagai tujuan dan ukuran (Putri, 2012). Balanced scorecard tidah hanya menghubungkan strategi dengan ukuran kinerja, melainkan melakukan pengukuran kinerja dari berbagai aspek yang terdapat pada organisai (Antari dan Sudana, 2016). Balance scorecard memerlukan rencana jangka panjang dan berkelanjutan untuk mewujudkan penilaian organisasi yang efektif (Olufemi et al., 2019). Indikator penilaian kinerja pada Disdukcapil Klungkung berdasarkan metode balance scorecard adalah sebagai berikut :

Tabel 2. Indikator Penilaian Berdasarkan Metode Balance Scorecard

\begin{tabular}{|c|c|}
\hline Prespektif Pada Balance Scorecard & Indikator Penilaian Kinerja \\
\hline Prespektif Keuangan & $\begin{aligned} & \text { Value For Money } \\
& \text { - } \text { Aspek Ekonomis } \\
& \text { - } \text { Aspek Efisiensi } \\
& \text { - } \text { Aspek Efektifitas }\end{aligned}$ \\
\hline Prespektif Pelanggan & $\begin{array}{l}\text { Customers Satisfation Index/ Indeks } \\
\text { Kepuasan Pelanggan }\end{array}$ \\
\hline Prespektif Proses Internal & Service Cycle Effisiensi (SCE) \\
\hline Prespektif Pertumbuhan dan Pembelajaran & Rasio Produktifitas Pegawai \\
\hline $\begin{array}{l}\text { Sumber: Data Penelitian, } 2019 \\
\quad \text { Kinerja Prespektif keuangan m } \\
\text { anggaran dana dari pada mencari keu } \\
\text { prespektif keuangan diukur menggunak } \\
\text { mengetahui tingkat ekonomis, efisiensi } \\
\text { keuangan. Program dikatakan ekonom } \\
\text { dengan optimal dan dapat menghemat a }\end{array}$ & $\begin{array}{l}\text { gkkup memaksimlan penggunaan } \\
\text { gan (Martello et al., 2008). Kinerja } \\
\text { lue for money yang bertujuan untuk } \\
\text { efektivitas dari kinerja prespektif } \\
\text { pabila program tersebut berjalan }\end{array}$ \\
\hline
\end{tabular}


Tabel 3. Pengukuran Ekonomi pada Alokasi dan Anggaran Biaya Dinas Kependudukan Dan Pencatatan Sipil Tahun 2018

\begin{tabular}{lcccc}
\hline \multicolumn{1}{c}{ Program/Kegiatan } & Anggaran & Realisasi & Penghematan & $\begin{array}{c}\text { Tingkat } \\
\text { Ekonomi } \\
(\%)\end{array}$ \\
\hline $\begin{array}{l}\text { Program Pelayanan } \\
\text { Kesekretariatan } \\
\text { Program Penataan }\end{array}$ & 1.361 .686 .114 & 1.304 .107 .498 & 57.578 .616 & 95,77 \\
$\begin{array}{l}\text { Administrasi } \\
\text { Kependudukan } \\
\text { Program Pelayanan }\end{array}$ & 409.771 .500 & 407.434 .255 & 2.337 .245 & 99,43 \\
$\begin{array}{l}\text { Pendaftaran } \\
\begin{array}{l}\text { Penduduk } \\
\text { Program Pelayanan }\end{array}\end{array}$ & 526.495 .300 & 513.651 .350 & 12.843 .950 & 97,56 \\
\begin{tabular}{l} 
Pencatatan Sipil \\
\hline
\end{tabular} & 223.415 .650 & 221.595 .225 & 1.820 .425 & 99,19 \\
\hline
\end{tabular}

Sumber : Data Penelitian, 2019

Berikut ini adalah Tabel yang menjelaskan mengenai pengukuran kinerja Disdukcapil Klungkung berdasarkan aspek Ekonomis. Berdasarkan data yang ditunjukkan dalam Tabel 3 diketahui bahwa Alokasi dan Anggaran Biaya Disdukcapil Klungkung tahun 2018 mengalami penghematan pada Program Pelayanan Kesekretariatan sebesar Rp. 57.578.616, Program Penataan Adimistrasi Kependudukan mengalami penghematan anggaran sebesar Rp. 2.337.245, Program Pelayanan Pendaftaran Penduduk mengalami penghematan sebesar Rp. 12.843.950, Program pelayanan Pencatatan Sipil mengalami penghematan sebsar Rp. 1.820.425.

Pengukuran tingkat ekonomis pada Disdukcapil Klungkung tahun 2018 pada program Program Pelayanan Kesekretariatan sebesar 95,77\%, Program Penataan Adimistrasi Kependudukan sebesar 99,43\%, Program Pelayanan Pendaftaran Penduduk sebesar 97,65\% dan Program pelayanan Pencatatan Sipil sebesar 99,19\%. Berdasarkan analisis perhitungan ini maka dapat disimpulkan bahwa Disdukcapil Klungkung mempunyai tingkat ekonomi yang ekonomis karena diperoleh hasil presentase dengan tingkat pencapaian yang mencapai kurang dari 100\%.Pengukuran tingkat efisiensi pada Disdukcapil Klungkung disajikan pada Tabel 4. Kinerja Disdukcapil Klungkung dikatakan efisien nilai yang diperoleh lebih dari $100 \%$.

Tabel 4. Pengukuran Efisiensi pada Alokasi dan Anggaran Biaya Dinas Kependudukan Dan Pencatatan Sipil Tahun 2018

\begin{tabular}{lcccc}
\hline \multicolumn{1}{c}{$\begin{array}{c}\text { Program/ } \\
\text { Kegiatan }\end{array}$} & $\begin{array}{c}\text { Penghematan } \\
\text { Anggaran }\end{array}$ & $\begin{array}{c}\text { Output } \\
(\%)\end{array}$ & Input (\%) & $\begin{array}{c}\text { Tingkat } \\
\text { Efisiensi (\%) }\end{array}$ \\
\hline $\begin{array}{l}\text { Program Pelayanan } \\
\text { Kesekretariatan }\end{array}$ & 57.578 .616 & 100 & 95,77 & 104,42 \\
$\begin{array}{l}\text { Program Penataan } \\
\text { Administrasi }\end{array}$ & 2.337 .245 & 100 & 99,43 & 100,57 \\
$\begin{array}{l}\text { Kependudukan } \\
\text { Program Pelayanan }\end{array}$ & 12.843 .950 & 100 & 97,56 & 102,50 \\
$\begin{array}{l}\text { Pendaftaran Penduduk } \\
\text { Program Pelayanan }\end{array}$ & 1.820 .425 & 100 & 99,19 & 100,82 \\
\hline Pencatatan Sipil & & & & \\
\hline Sumber : Data Penelitian, 2019 & & & &
\end{tabular}


Berdasarkan data pada Tabel 4 mengenai pengukuran kinerja keuangan Disdukcapil Klungkung berdasarkan aspek efisiensi pada program/kegiatan yang sudah dilaksanakan selama tahun 2018 diketahui bahwa setiap program/kegiatan sudah berjalan dengan efisien. Program pelayanan kesekretariatan memperoleh nilai $104,42 \%$ Program penataan administrasi kependudukan memperoleh nilai $100,57 \%$, program pelayanan pendaftaran penduduk memperoleh nilai $102,50 \%$, dan program pelayanan pencatatan sipil memperoleh nilai $100,82 \%$.

Berdasarkan analisis perhitungan ini maka dapat disimpulkan bahwa Disdukcapil Klungkung sudah berjalan dengan efisien, karena Dinas Kependudukan Dan Pencatatan Kabupaten Klungkung telah mampu mencapai keluaran yang maksimum dengan memanfaatkan anggaran yang ada.

Tabel 5. menyajikan pengukuran tingkat efektivitas pada Disdukcapil Klungkung. Efektivitas hanya melihat apakah suatu program telah mencapai tujuan yang telah ditetapkan sebelumnya (Mardiasmo, 2009 : 134). Efektivitas merupakan tingkat pencapaian hasil program dengan target yang ditetapkan (Purnamasari et al., 2014) Semakin tinggi nilai rasio efektivitas maka suatu kegiatan/program dikatakan lebih efektif.

Tabel 5. Pengukuran Efektivitas Pada Alokasi dan Anggaran Biaya Dinas Kependudukan Dan Pencatatan Sipil Tahun 2018

\begin{tabular}{|c|c|c|c|c|c|}
\hline Program/Kegiatan & Anggaran & Realisasi & $\begin{array}{c}\text { Target } \\
(\%)\end{array}$ & $\begin{array}{c}\text { Capaian } \\
\text { Kinerja } \\
(\%) \\
\end{array}$ & $\begin{array}{c}\text { Tingkat } \\
\text { Efektivitas } \\
(\%) \\
\end{array}$ \\
\hline $\begin{array}{l}\text { Program Pelayanan } \\
\text { Kesekretariatan } \\
\text { Program Penataan }\end{array}$ & 1.361.686.114 & 1.304.107.498 & 100 & 95,77 & 95,77 \\
\hline $\begin{array}{l}\text { Administrasi } \\
\text { Kependudukan } \\
\text { Program Pelayanan } \\
\text { Pendaftaran }\end{array}$ & 409.771 .500 & 407.434.255 & 100 & 99,43 & 99,43 \\
\hline $\begin{array}{l}\text { Penduduk } \\
\text { Program Pelayanan }\end{array}$ & 526.495 .300 & 513.651 .350 & 100 & 97,56 & 97,56 \\
\hline Pencatatan Sipil & 223.415 .650 & 221.595 .225 & 100 & 99,19 & 99,19 \\
\hline
\end{tabular}

Sumber : Data Penelitian, 2019

Berdasarkan data pada Tabel 5 mengenai pengukuran kinerja keuangan berdasarkan aspek efektivitas pada program/Kegiatan Disdukcapil Klungkung tahun 2018 didapatkan hasil tingkat efektivitas pada program pelayanan kesekretariatan sebesar 95,77\%, program penataan administrasi kependudukan sebesar $99,43 \%$, pada program pelayanan pendaftaran penduduk sebesar $97,56 \%$ dan pada program pelayanan pencatatan sipil tingkat efektivitasnya sebesar 99,19\%. Berdasarkan hasil pengukuran tersebut dapat dikatakan program/kegiatan Disdukcapil Klungkung selama tahun 2018 sudah berjalan dengan efektif karena memperoleh nilai $90 \%$ s/d $100 \%$ hal ini berarti Disdukcapil Klungkung telah berhasil mencapai tujuannya.

Hasil analisis yang diperoleh dari perhitungan aspek value for money pada Disdukcapil Klungkung tahun 2018 telah memenuhi kriteria yaitu ekonomis, efisien dan efektif sehingga dapat disimpulkan bahwa kinerja keuangan Disdukcapil Klungkung dinilai dengan value for money sudah baik. 
Prespektif pelanggan dalam organisasi sektor publik merupakan komponen paling penting dari keempat prespektif balance scorecard (A dan A, 2013). Organisasi sektor publik/pemerintahan harus memiliki tujuan untuk mengutamakan kesejahtraan dan kepuasan pelanggan dan stakeholdernya yaitu masyarakat (Narutomo, 2012). Pengukuran kepuasan pelanggan diukur menggunakan Customer Satisfation Index. Pengukuran kepuasan pelanggan menggunakan kuesioner tertutup yang disesuaikan dengan pedoman yang tercantum dalam Keputusan MENPAN Nomor KEP/25/M.PAN/2/2004.

Sebanyak 100 kuesioner yang terdiri dari 14 pertanyaan memenuhi syarat untuk diolah. Pengujian validitas menggunakan pearson correlation dilakukan dengan menggunakan program SPSS 18.0 for windows, menunjukkan hasil secara keseluruhan pertanyaan dianggap valid. Hasil uji reliabilitas untuk 14 pertanyaan menghailkan nilai cronbach's alpha sebesar 0,819 menunjukkan bahwa kuesioner sangat reliabel.

Dari 100 kuesioner yang terdiri dari 14 pertanyaan ditentukan interval kepuasan pengguna jasa untuk mengetahui tingkat kepuasan masyarakat. Skala yang digunakan untuk mengolah data :

$$
\begin{aligned}
\text { Interval } & =(\mathrm{IKmaks}-\mathrm{IKmin}): 4 \\
\text { IKMaks } & =\mathrm{PP} \times \mathrm{R} \times \mathrm{EXmaks} \\
& =100 \times 14 \times 4 \\
& =5.600 \\
\text { IKMin } & =\mathrm{PP} \times \mathrm{R} \times \mathrm{Exmin} \\
& =100 \times 14 \times 1 \\
& =1.400 \\
\text { Interval } & =(5.600-1.400): 4 \\
& =1.050
\end{aligned}
$$

Keterangan:

$\mathrm{R} \quad=$ Jumlah Responden keseluruhan

$\mathrm{PP} \quad=$ Jumlah Pertanyaan

EX $\min =$ Skor minimal yang bisa diberikan

EX max $=$ Skor maksimal yang bisa diberikan

Tabel 6. Interval Kepuasan Pelanggan

\begin{tabular}{cc}
\hline Interval & Kategori \\
\hline $1.400-2.450$ & Tidak Puas \\
$2.451-3.501$ & Kurang Puas \\
$3.502-4.552$ & Puas \\
$4.552-5.600$ & Sangat Puas \\
\hline
\end{tabular}

Sumber : Data Penelitian, 2019

Standar yang digunakan pada pengelolaan data adalah minimal mencapai pada interval antara 3.502 - 4.552 atau pada kategori puas. Pada tabel 4.13 skor terendah yang didapat dari penyebaran 100 kuesioner adalah mengenai kesopanan dan keramahan petugas dalam memberikan pelayanan sebesar 286 dan mengenai ketepatan waktu pelaynana sebesar 287 . 
Tabel 7. Indeks Kepuasan Masyarakat

\begin{tabular}{lc}
\hline \multicolumn{1}{c}{ Pertanyaan } & Total Nilai \\
\hline $\begin{array}{l}\text { Prosedur pelayanan yang di berikan oleh Disdukcapil Kabupaten } \\
\text { Klungkung memberikan kemudahan tahap pelaynanan }\end{array}$ & 290 \\
$\begin{array}{l}\text { Persyaratan yang diperlukan untuk mendapat pelaynanan sesuai } \\
\text { dengan pelaynanan yang diberikan }\end{array}$ & 334 \\
$\begin{array}{l}\text { Petugas memberi pelaynana dengan jelas sesuai dengan } \\
\text { kewenangannya }\end{array}$ & 303 \\
$\begin{array}{l}\text { Petugas memberikan pelayanan dengan disiplin dan sesuai dengan } \\
\text { waktu kerja berdasarkan ketentuan yang berlaku }\end{array}$ & 287 \\
$\begin{array}{l}\text { Petugas bertanggung jawab dalam penyelenggaraan dan penyelesaian } \\
\text { pelayanan }\end{array}$ & 301 \\
$\begin{array}{l}\text { Petugas memiliki kemampuan dan keterampilan dalam } \\
\text { penyelenggaraan dan penyelesaian pelayanan }\end{array}$ & 303 \\
$\begin{array}{l}\text { Petugas menyelesaikan pelayanan dalam waktu yang telah ditentukan } \\
\text { Petugas tidak membedakan golongan dan status masyarakat dalam } \\
\text { memberikan pelaynanan }\end{array}$ & 305 \\
$\begin{array}{l}\text { Adanya informasi mengenai kepastian biaya pelayanan } \\
\text { Petugas berperilaku sopan dan ramah dalam memerikan pelaynanan }\end{array}$ & 319 \\
$\begin{array}{l}\text { Pelaksanaan waktu pelayanan, sesuai dengan ketentuan yang telah } \\
\text { ditetapkan }\end{array}$ & 304 \\
$\begin{array}{l}\text { Biaya pelayanan sesuai dengan pelayanan yang diberikan } \\
\text { Kondisi saranan dan prasarana pelaynanan yang bersih, rapi dan } \\
\text { teratur memberikan rasa nyaman } \\
\text { Keamanan lingkungan unit pelaynanan memberikan rasa tenang dan } \\
\text { aman }\end{array}$ & 286 \\
\hline
\end{tabular}

Sumber : Data Penelitian, 2019

Secara keseluruhan Indeks kepuasan masyarakat yang diperoleh dari penyebaran 100 kuesioner pada Tabel 7 adalah mencapai pada 4.297. Sehingga pengguna jasa Dinas Kependudukan dan Pencatatan Sipil Kabupaten Klungkung dianggap puas dalam pelayanan yang didapatkan. Hal ini berarti pegawai telah mampu memenuhi harapan masyarakat menyangkut pelayanan instansi pemerintahan yang baik.

Prespektif proses internal adalah untuk mengukur efisiensi waktu proses pelayanan perekaman E-KTP yang diukur dengan Service Cycle Effisiensi (SCE). Dalam perhitunan waktu pemrosesan, jika rasio mendekati $100 \%$, akan menunjukkan tingkat tingginya koefisiensi dalam melakukan proses pelayanan. Dari 30 masyarakat yang diteliti pada proses perekaman E-KTP, rata-rata waktu yang diperlukan adalah 5,37 menit.. hasil ini akan dibandingkan dengan standar ukuran waktu yang digunakan oleh pegawai untuk melakukan proses perekaman E-KTP.

$$
\begin{aligned}
\text { Service Cycle Efficiency (SCE) }= & \frac{\text { Processing Time }}{\text { Troughput time }} \times 100 \% \\
= & \frac{5 \text { Menit }}{5,37 \text { Menit }} \times 100 \% \\
= & 93,17 \%
\end{aligned}
$$

Berdasarkan hasil perhitungan SCE, maka perbandingan antara proses waktu pelayanan perekaman E-KTP dengan standar waktu yang ditetapkan oleh 
para pegawai yaitu sebesar $93,17 \%$ tergolong tinggi karena nilainya mendekati 100\%. Hal ini berarti Dinas Kependudukan dan Pencatatan Sipil Kabupaten Klungkung termasuk efisien dalam waktu pelayanan yang diberikan kepada masyarakat.

Pengukuran perspektif pertumbuhan dan pembelajaran adalah mengukur produktivitas pegawai melalui jumlah data administrasi kependudukan yang dikeluarkan setiap tahunnya.

Tabel 8. Data Tingkat Produktivitas Pegawai Dinas Kependudukan Dan Pencatatan Sipil Kabupaten Klungkung

\begin{tabular}{cccccc}
\hline Tahun & $\begin{array}{c}\text { Jumlah } \\
\text { Pegawai }\end{array}$ & $\begin{array}{c}\text { Jumlah dokumen } \\
\text { kependudukan yang } \\
\text { dikeluarkan }\end{array}$ & Produktivitas & $\begin{array}{c}\text { Kenaikan/ } \\
\text { Penurunan }\end{array}$ & $\begin{array}{l}\text { Persentase } \\
(\%)\end{array}$ \\
\hline 2016 & 57 & 154.380 & 2.708 & & \\
2017 & 56 & 177.908 & 3.177 & 469 & $17,31 \%$ \\
2018 & 53 & 237.568 & 4.482 & 1.305 & $41,08 \%$ \\
\hline
\end{tabular}

Sumber : Data Penelitian, 2019

Tabel 8 menunjukkan tingkat produktivitas per pegawai sebesar 2.708 pada tahun 2016. Tahun 2017 tingkat produktivitas per pegawai sebesar 3.177 mengalami peningkatan sebesar 17,31\%. Tahun 2018 tingkat produktivitas pegawai mencapai 4.482 mengalami peningkatan sebesar $41,08 \%$ dari tahun sebelumnya. Tingkat produktivitas pegawai dari tahun 2016-2018 rata-rata 3.456 dokumen per pegawai. Kinerja Dinas Kependudukan dan Pencatatan Sipil berdasarkan perspektif pertumbuhan dan pembelajaran mengalami peningkatan yang baik atau positif.

Capaian kinerja pada tahun 2018 mengalami peningkatan yang lebih besar dari tahun sebelumnya, hal tersebut dikarenakan pada tahun 2016 dan tahun 2017 masih mengalami kendala pada terbatasnya distribusi blangko E-KTP dari pusat, sedangkan pada tahun 2018 ketersediaan blangko E-KTP sudah tercukupi sehingga percetakan dokumen E-KTP tidak mengalami hambatan. Peningkatan capain kinerja pada tahun 2018 juga terjadi dikarenakan inovasiinovasi yang ada telah dimaksimalkan sehingga membantu meningkatkan produktivitas dan pencatatan dan pencetakan dokumen kependudukan.

\section{SIMPULAN}

Berdasarkan pembahasan yang telah dilakukan maka dapat disimpulkan : Kinerja prespektif keuangan dinilai cukup baik karena berdasarkan penilaian menggunakan value for money Disdukcil Klungkung telah memenuhi aspek ekonomis, efisiensi dan efektivitas penggunaan dana; Kinerja dari prespektif pelanggan memperoleh total indeks kepuasan masyarakat mencapai 4.297 yang dapat dikategorikan masyarakat puas dengan pelayanan yang diberikan oleh Disdukcapil Klungkung; Kinerja prespektif proses internal dinilai menggunakan Service Cycle Efficiency (SEC) menunjukkan rasio nilai 93,17\% yang berarti tergolong efisien dalam pelayanan terhadap masyarakat yang melakukan perekaman E-KTP di Disdukcapil Klungkung; Kinerja prespektif pertumbuhan dan pembelajaran memperoleh tingkat produktivitas pegawai pada tahun 2018 mencapai 4.482 mengalami peningkatan sebesar 41,08\% dari tahun sebelumnya, berdasarkan prespektif pertumbuhan dan pembelajaran dapat dikategorikan 
sangat baik dikarenakan pegawai telah mampu memaksimalkan peningkatan produktivitas pegawai dalam pelayanan pencatatan dokumen kependudukan.

Penerapan Balance scorecard sebagai indikator penilaian kinerja pada Dinas Kependudukan dan Pencatatan Sipil Kabupaten Klungkung membantu masyarakat untuk mengetahui bagaimana kinerja Dinas Kependudukan dan Pencatatan Sipil Kabupaten Klungkung tidak hanya berdasarkan pertanggungjawaban anggaran penggunaan dana tetapi juga memberikan pelaporan kepada masyarakat mengenai proses dan keberhasilan pelayanan yang telah dilakukan.

Berdasarkan simpulan yang telah dilakukan maka dapat diberikan beberapa saran perbaikan untuk Disdukcapil Klungkung yaitu harus meningkatkan kinerja pengolahan keuangannya. Pada prespektif pelanggan skor terendah yang diperoleh dari kuesioner yang disebar adalah mengenai keramahan dan kesopanan dalam memberikan pelayanan. Diharapkan pegawai dapat meningkatkan keramahan dan kesopanan dalam memberikan pelayanan untuk masyarakat. Kinerja pada prespektif proses internal perlu dipertahankan. Pada prespektif pertumbuhan dam pembelajaran, diharapkan Disdukcapil klungkung terus mampu mempertahankan tingkat produktivitas pegawai dalam memberikan pelayanan pencatatan sipil dan pemberian dokumen kepndudukan untuk masyarakat. Saran bagi peneleti selanjutnya diharapkan dapat melakukan penelitian dengan data yang lebih lengkap sehingga dapat mendukung hasil pengukuran kinerja Disdukcapil Klungkung.

\section{REFERENSI}

A, S. and A, O. L. (2013) 'Influence Of Balanced Scorecard On Organizational Performance In Institutions Of Higher Learning In Kenya. A Case Study Of University Of Nairobi', 1(8), pp. 1-12.

Antari, N. W. Y. and Sudana, I. P. (2016) ‘Strategi dan Pengukuran Kinerja Badan Rumah Sakit Umum Tabanan Dengan Pendekatan Balance Scorecard', EJurnal Akuntansi Universitas Udayana, 15(3), pp. 2240-2268.

Aytül, Y. (2014) 'Implementing of Balanced Scorecard: Sample of Turkish Republic Ministry of Youth and Sport', Pamukkale University, Faculty of Sport Sciences, Sport Management Department, 150, pp. 754-761. doi: 10.1016/j.sbspro.2014.09.046.

Barnett, C. et al. (2010) 'Measuring the Impact and Value for Money of Governance \& Conflict Programmes'.

Behrouzi, F., Shaharoun, A. M. and Ma'aram, A. (2014) 'Applications of the balanced scorecard for strategic management and performance measurement in the health sector', Australian Health Review, 38, pp. 208217. doi: 10.1071/ AH13170.

Ciptani, M. K. (2013) 'Balance Scorecard Sebagai Pengukuran Kinerja Masa Depan: Suatu Pengantar', Jurnal Akuntansi \& Keuangan, Vol 2, No., pp. 21-35.

Davis, S. and Albright, T. (2004) 'An investigation of the effect of Balanced Scorecard implementation on financial performance', Management Accounting Research, 15, pp. 135-153. doi: 10.1016/j.mar.2003.11.001. 
Dewi, N. P. S. P., Sisdyani, E. A. and Putri, I. G. A. M. A. D. (2017) ‘Implementasi Balance Scorecard Dalam Penyusunan Rencana Strategis Di Rumah Sakit Umum Daerah Wangaya Kota Denpasar', E-Jurnal Akuntansi Universitas Udayana, 18(2017), pp. 965-995.

Etikan, I., Musa, S. A. and Alkassim, R. S. (2016) 'Comparison of Convenience Sampling and Purposive Sampling', American Journal of Theoretical and Applied Statistics, 5(1), pp. 1-4. doi: 10.11648/j.ajtas.20160501.11.

Farooq, A. and Hussain, Z. (2011) 'Balanced Scorecard Perspective On Change And Performance: A Study Of Selected Indian', (2008), pp. 37-48. doi: 10.20460/JGSM.2011515796.

Fitriyani, D. (2014) 'Balanced Scorecard: Alternatif Pengukuran Kinerja Organisasi Sektor Publik', Jurnal Cakrawala Akuntansi, 6(1), pp. 16-31. Available at: http://jca.unja.ac.id.

Franco-santos, M., Lucianetti, L. and Bourne, M. (2012) 'Contemporary performance measurement systems : A review of their consequences and a framework for research', Management Accounting Research. Elsevier Ltd, 23(2), pp. 79-119. doi: 10.1016/j.mar.2012.04.001.

Haryono, S. (2013) 'Balanced Score Card Untuk Mengukur Kinerja Sektor Publik', STIE YPN, IV(1).

Koufteros, X., John, A. and Lucianetti, L. (2014) 'The effect of performance measurement systems on firm performance: A cross-sectional and a longitudinal study', Journal of Operations Management. Elsevier B.V., 32(6), pp. 313-336. doi: 10.1016/j.jom.2014.06.003.

Liando, H. S., Sareng, D. P. E. and Elim, I. (2014) 'Analisis Kinerja Keuangan Pemerintah Kabupaten Kepulauan Sangihe Menggunakan Metode Value For Money', Jurnal Akuntansi Fakultas Ekonomi dan Bisnis, Jurusan Akuntansi Universitas Samratulangi, Manado, 2(3), pp. 1686-1694.

Limbu, W. P. and Sisdyani, E. A. (2016) 'Evaluasi Kinerja Dinas Pendapatan Daerah Kota Denpasar Berbasis Balance Scorecard', E- Jurnal Akuntansi Universitas Udayana, 15, pp. 1682-1710.

Lubis, A., Torong, Z. B. and Muda, I. (2016) 'The Urgency Of Implementing Balanced Scorecard System On Local Government In North SumatraIndonesia', I J A B E R, 14(11), pp. 7575-7590.

Martello, M., Watson, J. G. and Fischer, M. J. (2008) 'Implementing A Balanced Scorecard In A Not-For-Profit Organization', Journal of Business $\mathcal{E}$ Economics Research, 6(9), pp. 67-80.

Mcdonald, C., Walker, D. H. T. and Neeven, M. (2013) 'Towards a Project Alliance Value for Money Framework', Emerald Group Publishing Limited, $31(5 / 6)$, pp. 279-309.

Meillinda, I. G. A. A. and Suartana, I. W. (2018) 'Analisis Komparatif Kinerja Pda Lembaga Perkreditan Desa Kecamatan Mengwi dengan Metode Balanced Scorecard', 23(1), pp. 651-676. doi: doi.org/10.24843/EJA.2018.v23.i01.p25.

Narutomo, T. (2012) 'Penerapan Balanced Scorecard untuk Badan Penelitian dan Pengembangan Kementerian Dalam Negeri’, Jurnal Bina Praja, 4(3), pp. 189-200. doi: http:/ / dx.doi.org/10.21787/jbp.4.2012.189-200.

Nugrahini, I. A. P., Ratnadi, N. M. D. and Putri, I. G. A. M. A. D. (2016) ‘Penilaian 
Kinerja Berdasarkan Balanced Scorecard Pada Badan Penanaman Modal Dan Perijinan Daerah Kabupaten Tabanan', E-Jurnal Ekonomi dan Bisnis Universitas Udayana, 4, pp. 829-856.

Olufemi, F. J. et al. (2019) 'Improving public agency performance using balance scorecard in Lagos internal revenue service ( LIRS )', The Business and Management Review, 10(2), pp. 26-42.

Pebrianata, I. W. G. S. and Putri, I. G. A. M. A. D. (2014) 'Analisis Komparasi Kinerja Berbasis Balance Scorecard Pada LPD di Kecamatan Denpasar Timur', E-Jurnal Akuntansi Universitas Udayana, 6(2), pp. 340-354.

Purnamasari, I Made Desak, I., Suwendra, I. W. and Cipta, W. (2014) 'Analisis Kinerja Dinas Pendapatan Daerah Kabupaten Berdasarkan VAlue For Money Audit Atas Penerimaan Pendapatan Asli Daerah (PAD) Tahun 2007-2011', e-Journal Bisma Universitas Pendidikan Ganesha Jurusan Manajemen, 2.

Putri, I. G. A. M. A. D. (2012) 'Pengaruh Budaya Organisasi Terhadap Kinerja Dalam Prespektif Balance Scorecard', Jurnal Akuntansi Multiparadigma, 3, pp. 462-470. doi: 10.1192/bjp.205.1.76a.

Ridwan, R. et al. (2013) 'The Impact of the Balanced Scorecard on Corporate Performance: The Case of an Australian Public Sector Enterprise', International Business Research, 6(10), pp. 103-110. doi: 10.5539/ibr.v6n10p103.

Ronchetti, J. L. (2006) 'An Integrated Balanced Scorecard Strategic Planning Model for Nonprofit Organizations', journal of Practical Consulting, 1(1995), pp. 25-35.

Sharma, A. (2009) 'Implementing Balance Scorecard for Performance Measurement', The Icfai University Journal of Business Strategy, Vol. VI, N.

Sharma, B. and Gadenne, D. (2011) 'Balanced Scorecard Implementation in a Local Government Authority: Issues and Challenges', 70(2), pp. 167-184. doi: 10.1111/j.1467-8500.2011.00718.x.

Taufik, A. R., Djamhuri, A. and Saraswati, E. (2018) 'Performance Measurement Using Balance Scorecard (BSC) (Study at Hospitals In Pasusruan)', Journal Of Accointing and Business Education, 3(September), pp. 1-20.

Wiguna, I. G. E. P. and Wirawati, N. G. P. (2017) 'Penerapan Balanced Scorecard Pada Pengukuran Kinerja Trans SARBAGITA', E-Jurnal Akuntansi Universitas Udayana, 21, pp. 1072-1100.

Wood, D. J. (2010) 'Measuring Corporate Social Performance':, International Journal ofManagement Reviews (2010), 274. doi: 10.1111/j.14682370.2009.00274.x.

YS, P. D. S. and Ulupui, I. G. K. A. (2016) 'Kinerja Dinas Pariwisata Bali Berdasarkan Konsep Value For Money', E-Jurnal Akuntansi Universitas Udayana, 17, pp. 1635-1666. 